winds of elastic expansion, such as are the hot winds of India and Australia; winds which are distinct from convection currents, though, it may be, coexisting with and accelerating them. The relations of these winds to the barometric tides are very marked, but it does not seem that the differences of tidal pressure would suffice to generate them, were there not a movement of the air in the same direction arising from more persistent differences of pressure. They probably also depend much on local and irregular differences of pressure.

The air thus removed in the day-time from continental areas must, of course, collect over the nearest areas of evaporation, with the effect of diminishing the mid-day fall of pressure over those tracts; and thus seems to be explained those apparent anomalies in the magnitude of the mid-day semi-oscillation of the barometer to which, in the passages quoted from Mr. Buchan's memoir, he has drawn attention, viz., in the case of the Mediterranean area and the Atlantic coast of North America.

The direction in which this movement of the air takes place will, of course, vary with the locality, but there will always be, on an avcrage, a greater diurnal movement towards cast coasts than towards those facing to the west. 'This may be illustrated by the case of Calcutta and Bombay, and it is more extensively illustrated by the predominant westerly direction of the land-winds of India, and the cold westerly diurnal winds ${ }^{1}$ that blow across the high plains ( 17,000 to $19,000 \mathrm{feet}$ ) of the Changchenmo and Rupihu in Western Tibet. The reason is sufficiently obvious. As the great waves of pressure advance from east to west, the local barometric gradient of any place (in so far as it is determined by the diurnal oscillation) wiil be expressed by a tangent to the existing pliase of the wave. During the hottest part of the day, viz., from 9 or half-past 9 to half-past 4 or 5 , this gradient (which is the steepest and most prolonged of the four) inclines to the eastward, and increases the declivity towards east coasts arising from the excess of pressure over the land. In the opposite direction, viz., towards west coasts, it goes to diminish that declivity. At night the case is reversed. The west to east barometric gradient from Io P.M. to half-past 3 or 4 A.M. is in the same direction as that tending to produce an influx of air from the sea towards the lard on west coasts; this, however, is opposed to the land wind of the coast line, which is a true convection current, and arises from quite different causes; and, although traceable in the wird variation at Bombay, it there manifests itself only by decreasing the velocity of the former. There are, moreover, independent grounds for the inference that this compensating in-flow chiefly affects the higher strata of the atmosphere, while the day wind is chiefly produced in the lower and more heated strata. At Calcutta the easterly (or negative westerly) tendency of the wind at night is very prominently exhibited in the curve of diurnal variation, but although of longer duration it is at no time so intense as the westerly tendency in the early afternoon hours.

In like manner may be explained the difference of epoch of the corresponding phases of the semi-diurnal east and west variation at Calcutta and Bombay. The gradient of pressure, in so far as it depends on the semidiurnal oscillation, will, of course, be to the west with a rising pressure, and to the east with a falling pressure, and this normal tidal gradient is affected by the small difference of amplitude over land and sea, in such manner that its changes will be accelerated as affecting east coasts, and retarded as affecting west coasts. Now if we suppose that the acceleration in the one case and the retardation in the other amount to an hour or an hour and a half, and that the interval between the change in the direction of the gradients, and their effects on the wind, as manifested by the anemometer, is also about an hour

I This I state on the authority of Dr. Cayley, who assures me that on the high plains these afternoon winds are always from the west. and a half, we should roughly reproduce the conditions shown to exist at Calcutta and Bombay respectively.

According to this view, the local static pressure of the atmosphere, apart from irregular movements, is shown by the height of the barometer at the hours of minimum pressure, and the difference of these expresses the weight of the atmosphere removed and restored by the oscillatory movements chiefly between land and sea.

I should add, in conclusion, that this communication is merely a résumé of some of the more salient topics discussed in two papers, "On the Winds of Calcutta," and "The Theory of Winds of Elastic Expansion," which will shortly be published in extenso elsewhere.

H. F. BLANFORD

\section{CARBONIFEROUS LAND SHELLS}

I $N$ a recent visit to the South Loggius, in Nova Scotia, in which $I$ was assisted in the examination of the cliff by Mr. Albert J. Hill, Manager of the Cumberland Coal Mine, we found a number of well-preserved shells of Pupa vetusta, in the indurated clay, filling an erect sigillaria, in a bed considerably higher than those in which the shell was previously known. It is nearly in the middle of group xxvi. of my section of the South Loggius, 222 feet above the main coal-seam, 842 feet above the bed in which the species was first recognised by Sir C. Lyell and myself, and about 2,000 feet above the lowest bed in which I have yet found it. It thus appears that this little pulmonate continued to flourish in the carboniferous swamps, after its remote ancestors had been covered with 2,000 feet of sediment, including many beds of coal, and nearly the whole thickness of the productive coal-measures. Conulus priscus, the only other land-snail found in this section, on the other hand occurs only, so far as known, in the lowest of the beds above-mentioned. Two other carboniferous land-shells, Pupa vermilionensis, Bradley, and Dawsonella Meekr, Bradley, have been found in the coal-field of Illinois; and it is worthy of remark that, according to Dr. P. P. Carpenter, all the four species belong to distinct generic or sub-generic forms, and that all these forms are still represented on the American Continent.

On the same visit, we were so fortunate as to find another large sigillarium stump, rich in reptilian remains, which it is hoped may, on examination, afford new species and further information on those already known.

\section{J. W. DAWSON}

\section{THE BIRDS OF KERGUELEN'S LAND 1}

$A S$ regards the publication of results achieved by the naturalists accompanying the recent Transit expedition, our American friends appear to be getting the start of us. While we are engaged in issuing " preliminary reports," they have already arranged and classified their collections, and are beginning to publish their discoveries. The specimens of birds obtained by Dr. Kidder, surgeon and naturalist attached to the astronomical party at Kerguelen's Land, or Desolation Island, have been placed for determination in the hands of Dr.E. Coues -one of the most competent zoologists in the United States-and the result has been the very interesting memoir now before us. We knew already that Kerguelen's Land was not an inviting place of residence for the more highly organised animals, and that few birds were to be found there. We know now what those few are, and have full particulars about most of them, their lives, and habits. According to Dr. Coues' determination, Dr.

I "Bulletin of the United States National Museum," No. 2. Contributions to the Natural History of Kerguelen Island, made in connection with the American Transit of Venus Expedition, 1874-75. By J. H. Kidder, M.D. I. Ornithology. Edited by Dr. Elliott Coues, U.S.A., 8vo. 52 pp. (Washington, $18_{75}$. ] 